\title{
THE AXIS OF ORIENTATION OF THE SYNLOPHE in the Heligmosomoidea (Nematoda, Trichostrongylna): A NEW APPROACH
}

\author{
DURETTE-DESSET M.C.* \& DIGIANI M.C.*
}

\section{Summary:}

The definition of the axis of orientation of the synlophe is modified for the Heligmosomoidea so that one or two axes may be recognized. When two axes are present, their inclinations to the sagittal axis are different on the right and left sides, and we propose to name them right axis and left axis, respectively. During the course of evolution, starting from a single oblique axis (plesiomorphic state), an independent rotation of this axis on the right and left sides may bring about a double-axis state with a different inclination on both sides (derived state). When the rotation reaches $90^{\circ}$ for both sides, the axis becomes simple once again and is superimposed to the frontal axis (most derived state).

KEY WORDS : Nematoda, Trichostrongylina, Heligmosomoidea, synlophe, axis of orientation, right axis, left axis.

\section{INTRODUCTION}

T $\mathrm{n}$ the Trichostrongylina, following the hypotheses of the evolution of the synlophe laid down by Durette-Desset $(1971,1985)$, the axis of orientation is defined as the axis which separates the cuticular ridges into two groups in which the tips point in opposing directions. The study of the synlophe being done on transverse sections of the animal, the axis corresponds in fact to a plane if we take into consideration the entire animal.

In the Cooperiidae (Trichostrongyloidea) and the Molineoidea, the axis of orientation of the synlophe is confounded with the sagittal axis of the parasite and therefore, deals with an axis of symmetry, the number, the size of the ridges and the distance between them being symmetrical for the right and left sides. This type of synlophe is considered as plesiomorphic since a externo-bilateral symmetry is shared by all nematodes. In the Heligmosomoidea, the axis of orientation is never superimposed to the sagittal axis. It is (almost)

\footnotetext{
* Département de Systématique et Évolution, UMR 7138 Systématique, Adaptation, Évolution, associée au CNRS, UMS 0603 Muséum national d'Histoire naturelle, CP 52, 61, rue Buffon, 75231 Paris cedex 05, France.

Correspondence: M.C. Durette-Desset.

Tel: 33 (0)1 40793509 - Fax: 33 (0)1 40793499.
}

E-mail: mcdd@mnhn.fr
Résumé : L'axe D'orientation DU Synlophe CHEZ les Heligmosomoidea (Nematoda, Trichostrongylina) : une nouvelle APPROCHE

La définition de l'axe d'orientation du synlophe est modifiée chez les Heligmosomoidea de telle sorte qu'un ou deux axes puissent être reconnus. Lorsque deux axes sont présents, leur inclinaison sur l'axe sagittal est différente sur chaque face latérale, et nous proposons de nommer ces axes, axe droit et axe gauche. Au cours de l'évolution, à partir d'un axe oblique unique /stade plésiomorphe), une rotation asynchrone de cet axe sur les côtés droit et gauche aurait abouti à un axe double ayant une inclinaison différente de chaque côté (stade dérivé). Lorsque la rotation atteint $90^{\circ}$ sur les deux côtés, l'axe redevient unique et se confond avec l'axe frontal (stade le plus évolué).

MOTS CLÉS : Nematoda, Trichostrongylina, Heligmosomoidea, synlophe, axe d'orientation, axe droit, axe gauche.

always orientated from the right ventral quadrant to the left dorsal quadrant, and its inclination with respect to the sagittal axis varies. It may be oblique in relation to the sagittal axis or inclined at $90^{\circ}$ to this latter and thus confounded with the frontal axis passing through the middle of the lateral fields.

During recent studies on some Heligmosomoidea belonging to the genera Vexillata (Travassos, 1937) (Ornithostrongylidae), Hassalstrongylus Durette-Desset, 1971 (Heligmonellidae) and Heligmonoides Baylis, 1928 (Heligmonellidae) (Durette-Desset \& Digiani, 2005; Digiani \& Durette-Desset, 2003) we have noticed that the degree of inclination of the axis of orientation of the synlophe to the sagittal axis was different on the right and left sides of the animal. However, this difference in the inclination does not alter the orientation of the axis, which is in all cases directed from the right ventral quadrant to the left dorsal quadrant. This has induced us to refine the definition of the axis of orientation in the Heligmosomoidea, taking the genera Vexillata and Heligmonoides as examples.

\section{MATERIAL AND METHODS}

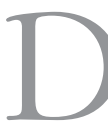

ata come either from the literature or from the study of identified material deposited in the Helminthological Collections of the Muséum 
national d'Histoire naturelle (MNHN): Vexillata chabaudi Yoyotte-Vado, 1972, MNHN 149 BA, syntype female; Vexillata petteri Durette-Desset, 1970a, MNHN 777 M, syntype male; Vexillata dessetae Denké, 1977, MNHN 1047 HA, syntype female; Vexillata legallae Denké, 1977, MNHN 1054 HA, syntype female; Heligmonoides parvulus (Desset, 1966), MNHN 50 SA, syntype female; Heligmonoides speciosus (Konno, 1958), MNHN 698 F, syntype male. The methods for studying the synlophe are those explained by Durette-Desset (1985). For each section, angles were measured several times and an error of $\pm 1^{\circ}$ was found. The nomenclature used above family group follows Durette-Desset \& Chabaud (1993). "Frontal axis" refers to the frontal axis passing through the middle of the lateral fields. In the tables, "unusable data" is used with the following meaning: calculating the degree of inclination of the axis (axes) of orientation can be a difficult task from data found in the literature for several reasons: in some cases, the lateral fields are not indicated, in other cases the body section delimited by the hypodermis is not centred and is displaced with respect to the cuticle as a result of the cutting of the section. In both cases, we preferred not to take these data into consideration.

\section{RESULTS}

\section{Genus Vexillata Travassos, 1937}

1 - Data from the literature (Table I).

2 - New data of the synlophe of four species at midbody (Fig. 1).

Vexillata chabaudi, female (Fig. 1A) - 11 cuticular ridges: two left forming carene, five dorsal, four ventral of inequal size and without well-defined gradient of size. Dorsal ridge adjacent to right lateral field smallest. Single axis of orientation directed from right to left and inclined at $90^{\circ}$ to sagittal axis.

Vexillata dessetae, female (Fig. 1B) - 12 cuticular ridges: two left forming carene, five dorsal, five ventral of inequal size and without gradient of size. Carene strongly developed. Ventral ridge adjacent to right lateral field smallest. Double axis of orientation directed from right ventral quadrant to the left; right axis inclined at $73^{\circ}$ to sagittal axis and left axis at $90^{\circ}$.

Vexillata legallae, female (Fig. 1C) - 12 cuticular ridges: two left forming carene, five dorsal, five ventral. Carene most developed and ventral ridge adjacent to right lateral field, smallest. All other ridges with double

\begin{tabular}{|c|c|c|}
\hline & Males & Females \\
\hline Species & Right & Right \\
\hline V. armandae & $90^{\circ} \quad 90^{\circ}$ & $90^{\circ} \quad 90^{\circ}$ \\
\hline Gardner et al., 1994 & after Gardner et al., 1994 & after Falcón et al., 2001 \\
\hline V. chabaudi & $90^{\circ} \quad 90^{\circ}$ & $90^{\circ} \quad 90^{\circ}$ \\
\hline Yoyotte-Vado, 1972 & after Yoyotte-Vado, 1972 & new data \\
\hline V. chitwoodi & $90^{\circ} \quad 60^{\circ}$ & $90^{\circ} \quad 60^{\circ}$ \\
\hline Durette-Desset \& Digiani, 2005 & after Durette-Desset \& Digiani, 2005 & after Durette-Desset \& Digiani, 2005 \\
\hline V. convoluta & $90^{\circ} \quad 60^{\circ}$ & $90^{\circ} \quad 65^{\circ}$ \\
\hline Caballero \& Cerecero, 1943 & after Durette-Desset, 1972 & after Durette-Desset, 1972 \\
\hline$V$. dessetae & $75^{\circ} \quad 53^{\circ}$ & $90^{\circ} \quad 73^{\circ}$ \\
\hline Denké, 1977 & after Denké, 1977 & new data \\
\hline V. legallae & $90^{\circ}$ & $60^{\circ}$ \\
\hline Denké, 1977 & after Denké, 1977 & new data \\
\hline V. liomyos & $90^{\circ} \quad 90^{\circ}$ & $90^{\circ} \quad 90^{\circ}$ \\
\hline Falcón-Ordaz et al., 2001 & after Falcón-Ordaz et al., 2001 & after Falcón-Ordaz et al., 2001 \\
\hline V. noviberiae & $90^{\circ} \quad 80^{\circ}$ & $90^{\circ} \quad 80^{\circ}$ \\
\hline (Dikmans, 1935) & after Durette-Desset \& Digiani, 2005 & after Durette-Desset \& Digiani, 2005 \\
\hline$V$. petteri & $90^{\circ} \quad 90^{\circ}$ & $90^{\circ} \quad 90^{\circ}$ \\
\hline Durette-Desset, 1970a & new data & after Denké, 1977 \\
\hline V. scorzai & $90^{\circ} \quad 90^{\circ}$ & $90^{\circ}$ \\
\hline Guerrero, 1984 & after Guerrero, 1984 & after Guerrero, 1984 \\
\hline V. tejerai & $90^{\circ} \quad 90^{\circ}$ & $90^{\circ} \quad 90^{\circ}$ \\
\hline Guerrero, 1984 & after Guerrero, 1984 & after Guerrero, 1984 \\
\hline V. vexillata & $90^{\circ} \quad 90^{\circ}$ & $90^{\circ} \quad 90^{\circ}$ \\
\hline (Hall, 1916) & after Durette-Desset, 1978 & after Durette-Desset, 1978 \\
\hline
\end{tabular}

In the males, the right axis is inclined from $53^{\circ}$ to $90^{\circ}$ to the sagittal axis, the left axis from $75^{\circ}$ to $90^{\circ}$. In the females, the right axis is inclined from $60^{\circ}$ to $90^{\circ}$ to the sagittal axis, the left axis at $90^{\circ}$.

"New data": from the study of the material deposited in the Helminthological Collections of the Muséum national d'Histoire naturelle de Paris.

* The author did not specify whether the body section was made on a male or a female, but in the text a synlophe identical for both sexes is described.

Table I - Degrees of inclination of the axes of orientation to the sagittal axis in the species of the genus Vexillata Travassos, 1937 at midbody. 
decreasing gradient of size from right to left on dorsal and ventral sides. Double axis of orientation directed from right ventral quadrant to the left; right axis inclined at $60^{\circ}$ to sagittal axis and left axis at $90^{\circ}$.

Vexillata petteri, male (Fig. 1D) - 11 cuticular ridges: two left forming carene, four dorsal, five ventral. Carene most developed and ventral ridge adjacent to right lateral field, smallest. All other ridges with double decreasing gradient of size from right to left on dorsal and ventral sides. Single axis of orientation directed from right to left and inclined at $90^{\circ}$ to sagittal axis.

\section{Remarks}

Among the 11 species of the genus Vexillata, two groups are distinguished according to the inclination of the axis of orientation of the synlophe on the right and left sides. Furthermore, the inclination may be similar or different in both sexes of the same species (Table I, Fig. 2A-D).
Group a) - In five species, on the right side, the axis is inclined from $53^{\circ}$ to $80^{\circ}$ to the sagittal axis in the male (Fig. 2A) and from $60^{\circ}$ to $80^{\circ}$ in the female (Fig. 2C). On the left side it is inclined from $75^{\circ}$ to $90^{\circ}$ to the sagittal axis in the male (Fig. 2A), at $90^{\circ}$ to the sagital axis in the female (Fig. 2C).

Group b) - In seven species, the axis is sub-frontal on both sides and for both sexes (Fig. 2B and D).

Comparing the degree of inclination of the axis for both sides (regardless of sex), it is more pronounced on the left side (five species) or the same on both sides (seven species).

Comparing the degree of inclination of the axis on each side for both sexes: on the right side, the inclination is the same in both sexes (height cases), more pronounced in the male (one case) or more pronounced in the female (two cases); on the left side, the inclination is the same in both sexes (10 cases) or more pronounced in the female (one case).

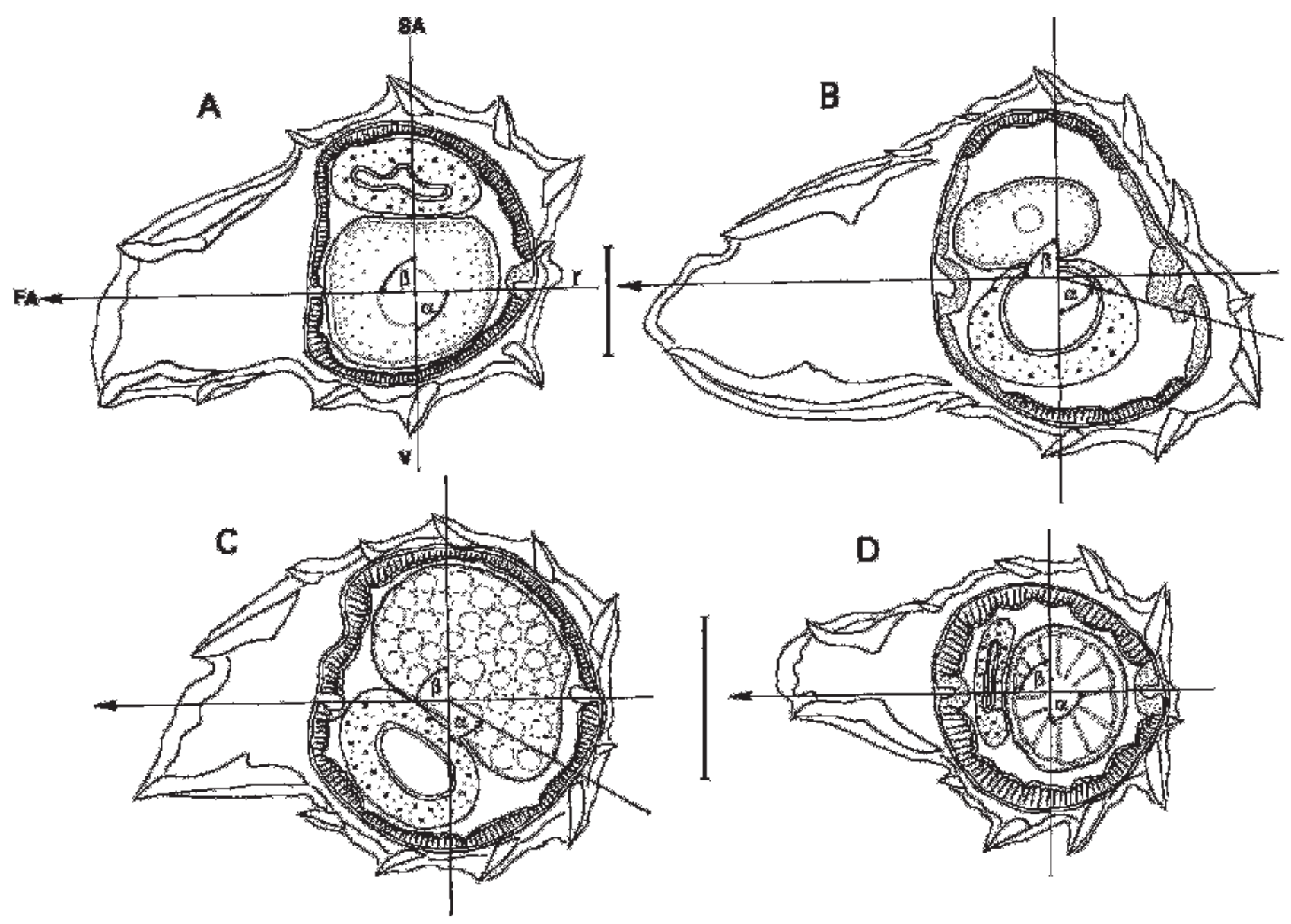

Fig. 1 - Transverse sections at mid-body of four species of the genus Vexillata Travassos, 1937. A. V. chabaudi Yoyotte-Vado, 1972, syntype female, $8.7 \mathrm{~mm}$ long, section at $4.5 \mathrm{~mm}$ from apex; $\alpha=\beta=90^{\circ}$. B. $V$. dessetae Denké, 1977 , syntype female, $9.0 \mathrm{~mm}$ long, section at $5 \mathrm{~mm}$ from apex; $\alpha=73^{\circ}, \beta=90^{\circ}$. C. V. legallae Denké, 1977 , syntype female, $3.7 \mathrm{~mm}$ long, section at $2.1 \mathrm{~mm}$ from apex; $\alpha=60^{\circ}$, $\beta=90^{\circ}$. D. $V$. petteri Durette-Desset, 1970a, syntype male, $3.2 \mathrm{~mm}$ long, section at $1.5 \mathrm{~mm}$ from apex; $\alpha=\beta=90^{\circ}$.

All sections are orientated as A. Axis (axes) of orientation represented by the arrow. $\alpha$ : angle of inclination of the right axis to the sagittal axis. $\beta$ : angle of inclination of the left axis to the sagittal axis.

Abbreviations: r: right side; v: ventral side; SA: sagittal axis; FA: frontal axis passing through the lateral fields. Scales: $30 \mu \mathrm{m}$. 


\section{Genus Vexillata}

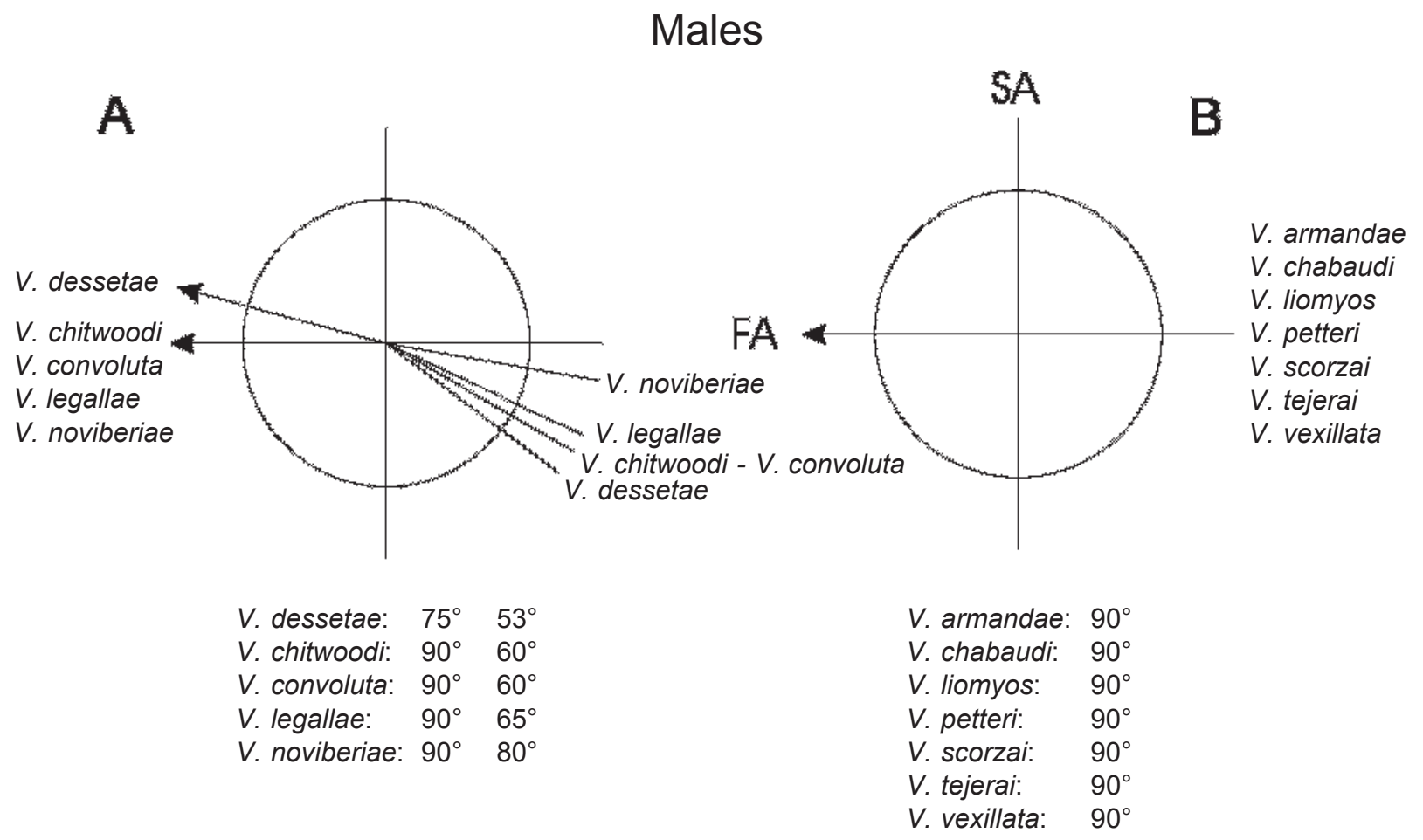

Females

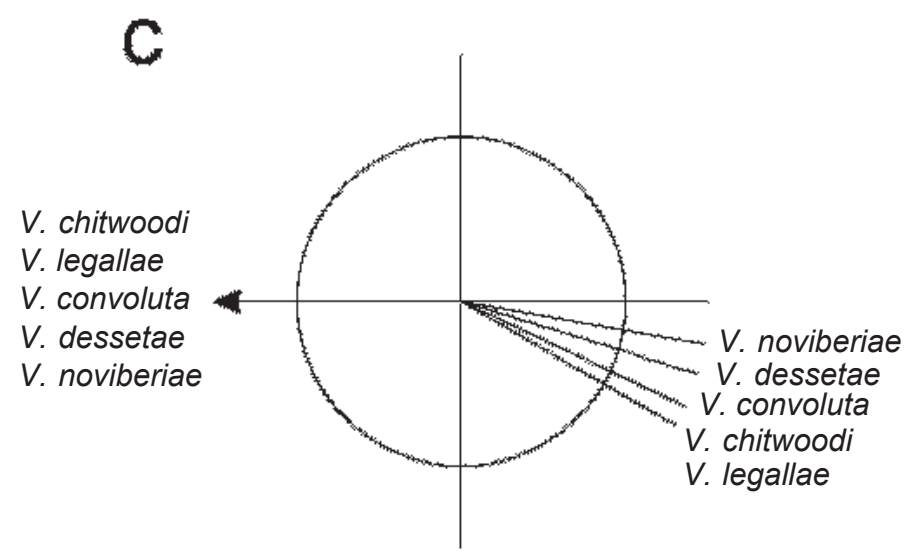

V. chitwoodi: $90^{\circ} \quad 60^{\circ}$

V. legallae: $90^{\circ} 60^{\circ}$

V. convoluta: $90^{\circ} 65^{\circ}$

V. dessetae: $90^{\circ} 73^{\circ}$

V. noviberiae: $90^{\circ} 80^{\circ}$

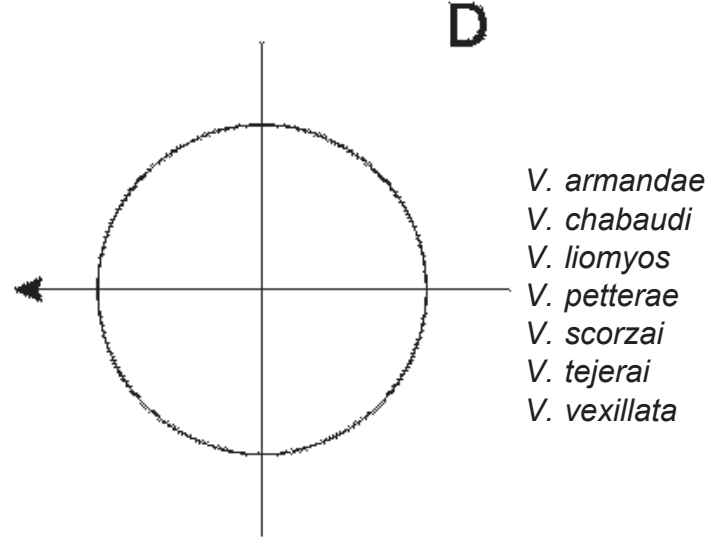

V. armandae: $90^{\circ}$

V. chabaudi: $90^{\circ}$

V. liomyos: $90^{\circ}$

V. petteri: $\quad 90^{\circ}$

V. scorzai: $\quad 90^{\circ}$

V. tejerai: $\quad 90^{\circ}$

V. vexillata: $90^{\circ}$

Fig. 2. - Diagrams of the various degrees of inclination of the axes of orientation to the sagittal axis in the species of the genus Vexillata Travassos, 1937 at mid-body.

In the males, right axis inclined from $53^{\circ}$ to $90^{\circ}$ to the sagittal axis, left axis from $75^{\circ}$ to $90^{\circ}$ (A, B). In the females, right axis inclined from $60^{\circ}$ to $90^{\circ}$ to the sagittal axis, left axis at $90^{\circ}$ (C, D).

All the diagrams are orientated as D. The degree of inclination of the species (single axis or left axis/right axis) is listed under each diagram. Abbreviations: FA: frontal axis; SA: sagittal axis; l: left side; v: ventral side. 


\section{Genus Heligmonoides Baylis, 1928}

1 - Data from the literature (Table II).

2 - New data of the synlophe of two species at midbody (Fig. 3).

Heligmonoides parvulus, female (Fig. 3A) - 22 cuticular ridges: four left forming carene, eight dorsal, 10 ventral of unequal size and without gradient of size. Ridges of carene strongly developed. Left ventral ridges and right dorsal ridges more developed than right ventral and left dorsal ridges. Double axis of orientation directed from right ventral to left dorsal quadrant; right axis inclined at $30^{\circ}$ to sagittal axis and left axis at $76^{\circ}$. Heligmonoides speciosus male (Fig. 3B) - 26 cuticular ridges: four left forming carene, eight dorsal, 14 ventral of unequal size and without gradient of size. Ridges of carene most developed. Left ventral ridges and right dorsal ridges of equivalent size and more developed than left dorsal and right ventral ridges, which are also of equivalent size. Double axis of orientation directed from right ventral to left dorsal quadrant; right axis inclined at $35^{\circ}$ to sagittal axis and left axis at $55^{\circ}$.

Remarks

In the genus Heligmonoides, although the data are somewhat fragmentary since the synlophe of both sexes is only known in three species out of 11 , the same phenomenon is observed, i.e a different inclination on each side of the axis of orientation, which is more or less pronounced to the sagittal axis (Table II, Fig. 4 A-D). Two groups are distinguished:

Group a) having a different inclination on both sides. It includes six species, in which the axis is inclined on the right side from $35^{\circ}$ to $50^{\circ}$ to the sagittal axis in the males (data known for four species) (Fig. 4 A) and from $30^{\circ}$ to $50^{\circ}$ in the females (data known for four species) (Fig. 4C). It is inclined on the left side from $55^{\circ}$ to $65^{\circ}$ in the males (Fig. $4 \mathrm{~A}$ ) and from $55^{\circ}$ to $76^{\circ}$ in the females (Fig. 4C).

Group b) having the same inclination on both sides. It includes H. ikeharai (both sexes) and $H$. taiwanensis (male) (Fig. 4B and D).

Comparing the degree of inclination of the axis for both sides (regardless of sex), it is the same (two cases) or more pronounced on the left side (all other cases). Comparing the degree of inclination on each side for both sexes (when the synlophe of both sexes is known i.e. three cases), on the right side, the inclination is the same in both sexes (two cases) or more pronounced in the male (one case); on the left side, the inclination is the same in both sexes (one case) or more pronounced in the female (two cases).

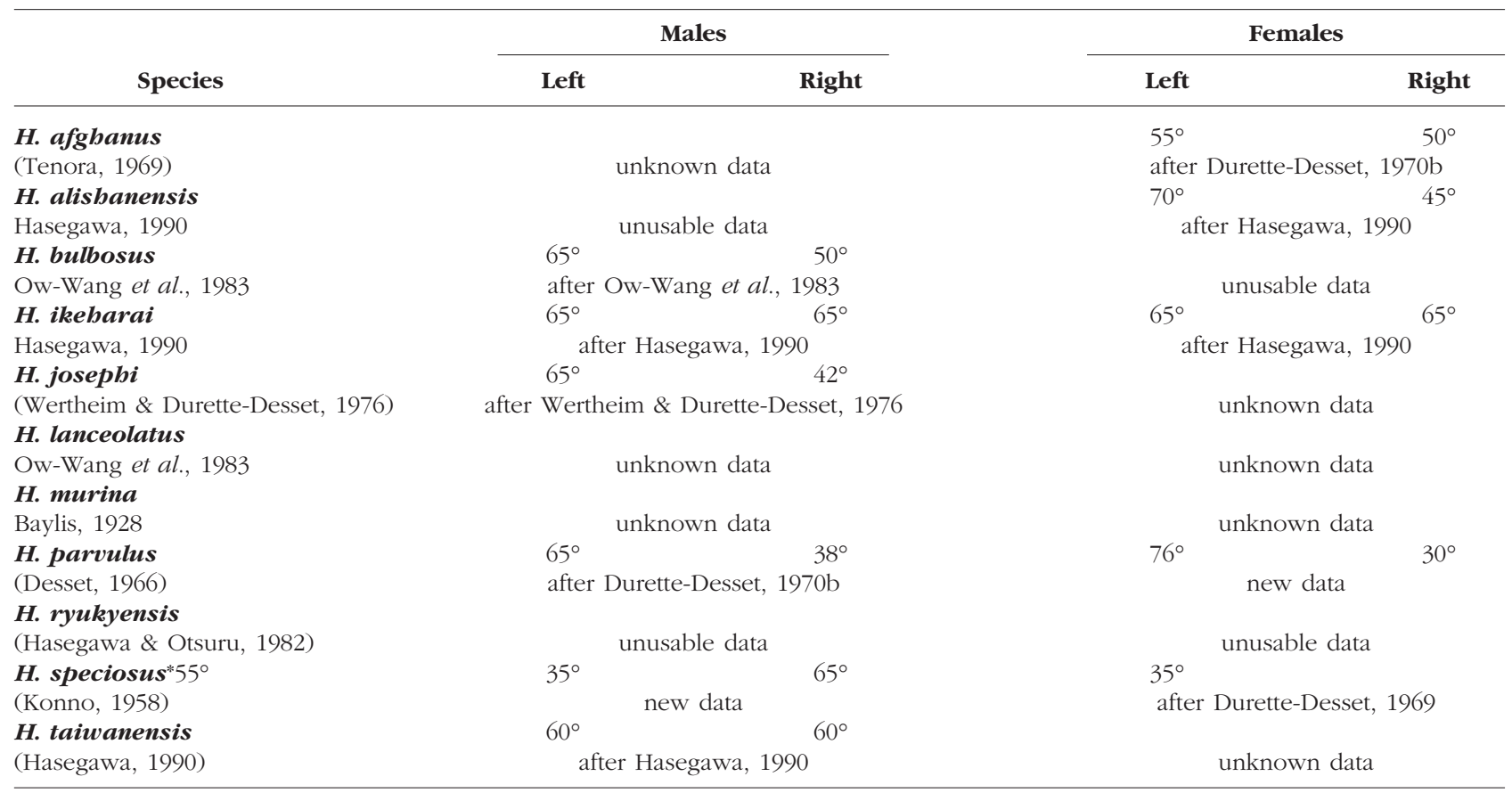

In the males, the right axis is inclined from $35^{\circ}$ to $65^{\circ}$ to the sagittal axis, the left axis from $55^{\circ}$ to $65^{\circ}$. In the females, the right axis is inclined from $30^{\circ}$ to $65^{\circ}$ to the sagittal axis, the left axis from $55^{\circ}$ to $76^{\circ}$.

"New data": from the study of the material deposited in the Helminthological Collections of the Muséum national d'Histoire naturelle de Paris.

"Unusable data": the lateral fields are not indicated (H. ryukyensis) or the body section delimited by the hypodermis is not centred and is displaced with respect to the cuticle as a result of the cutting of the section (H. alishanensis, H. bulbosus)

Table II - Degrees of inclination of the axes of orientation to the sagittal axis in the species of the genus Heligmonoides Baylis, 1928 at mid-body. 

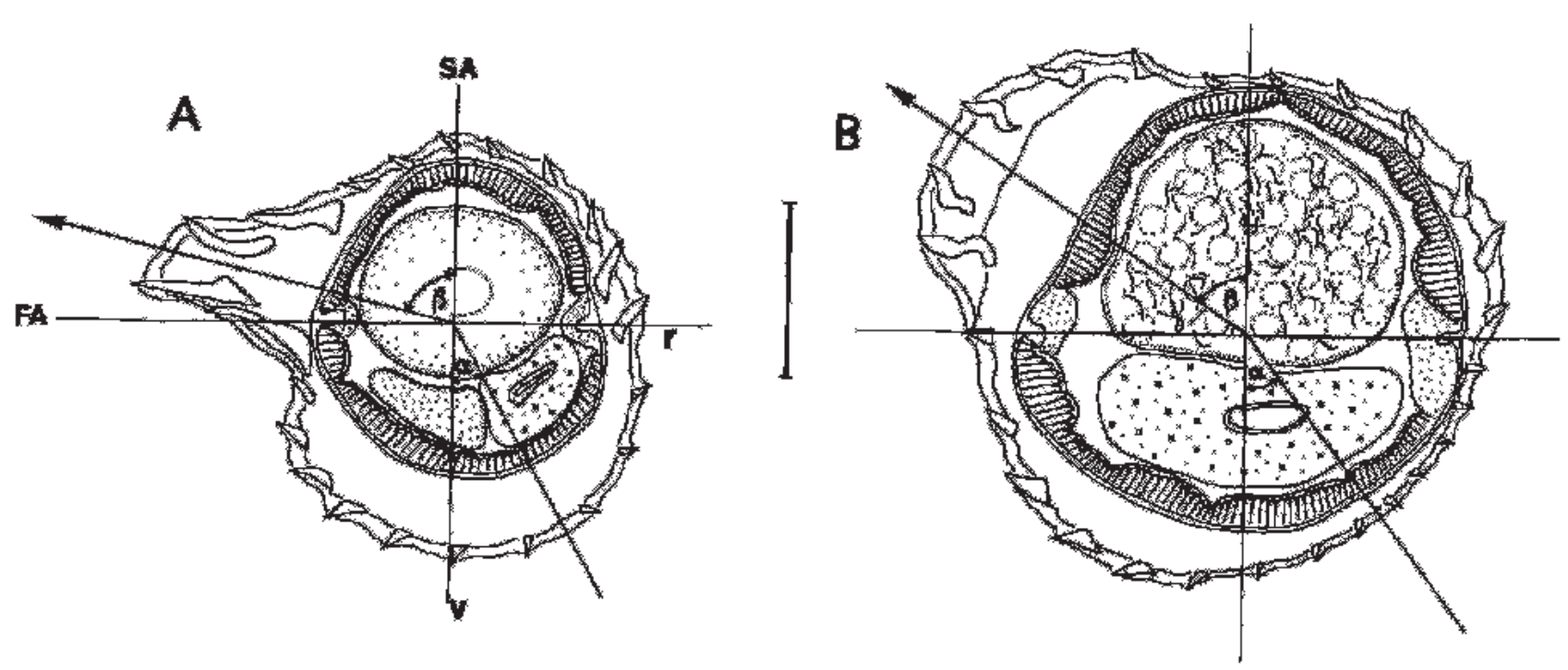

Fig. 3. - Transverse sections at mid-body of two species of the genus Heligmonoides Baylis, 1928. A. H. parvulus (Desset, 1966), syntype female, $2.25 \mathrm{~mm}$ long, section at $1.050 \mathrm{~mm}$ from apex; $\alpha=30^{\circ}, \beta=76^{\circ}$. B. H. speciosus (Konno, 1958), syntype male, $3.5 \mathrm{~mm}$ long, section at $1.75 \mathrm{~mm}$ from apex; $\alpha=35^{\circ}, \beta=55^{\circ}$.

Both sections are orientated as A. Axis (axes) of orientation represented by the arrow. $\alpha$ : angle of inclination of the right axis to the sagittal axis. $\beta$ : angle of inclination of the left axis to the sagittal axis.

Abbreviations: r: right side; v: ventral side; SA: sagittal axis; FA: frontal axis passing through the lateral fields. Scales: $30 \mu \mathrm{m}$.

\section{DISCUSSION}

$\mathrm{F}$ rom the examples of the species of the genera Vexillata and Heligmonoides, we can see that the degree of inclination of the axis in a single specimen is either the same on both sides or more pronounced on the left side.

When it is possible to compare both sexes of the same species, the relative inclination varies on the right side (i.e. it may be the same in both sexes, more pronounced in the males or more pronounced in the females), whereas on the left side, it is the same in both sexes or more pronounced in the females, but never more pronounced in the males (Tables I and II).

From a geometric point of view, an axis has only one inclination. In the species having a different inclination for the right and left sides, there are therefore two axes, one on each side. In view of this observation, we propose to modify the definition of the axis of orientation of the cuticular ridges in the Heligmosomoidea as follows: single or double axis passing through the intersection of the sagittal axis and the frontal axis. The axis (axes) separate(s) the cuticular ridges into two groups in which the tips point in opposing directions. It (they) is (are) always orientated from the right ventral quadrant to the left dorsal quadrant of the body (except Vaucherus Durette-Desset, 1980 , where the axis is orientated from the right dorsal quadrant to the left ventral quadrant). When two axes are present, their inclinations are different on the right and left sides and we propose to name them, right axis and left axis, respectively. We think it would be better in the description of a new species to clearly separate the description of both sides and, if possible, to provide a section at mid-body of both sexes.

Due to these new elements, it appears that the systematic position of some genera should be modified. The genus Vexillata, belonging up to now to the Ornithostrongylidae, has been characterized by a symmetrical synlophe in relation to the frontal axis (DuretteDesset, 1971). However, this is not the case of some species of Vexillata, in which only the most derived species acquire a symmetrical synlophe, the rest of the species having a double axis with different inclinations on the left and right sides. Dr. J. Falcón-Ordaz (UNAM, Mexico) who, using cladistic analysis is studying a taxonomic and phyletic revision of the species of this genus also thinks that Vexillata does not belong to the Ornithostrongylidae (J. Falcón-Ordaz, personnal communication).

From a phyletic point of view, the presence of two axes with a different inclination means that during the course of evolution, the two sides of the animal have evolved with an independent rotation of the axis of orientation. In the two genera studied, the rotation of the left axis is the more pronounced.

The fact of the axis being single or double does not alter in any way the principles of the evolution of the synlophe proposed by Durette-Desset $(1971,1985)$ i.e. the rotation of the axis of orientation whose inclination is more and more pronounced with respect to the sagittal axis. With this new approach, we consider that, 


\section{Genus Heligmonoides}

\section{Males}

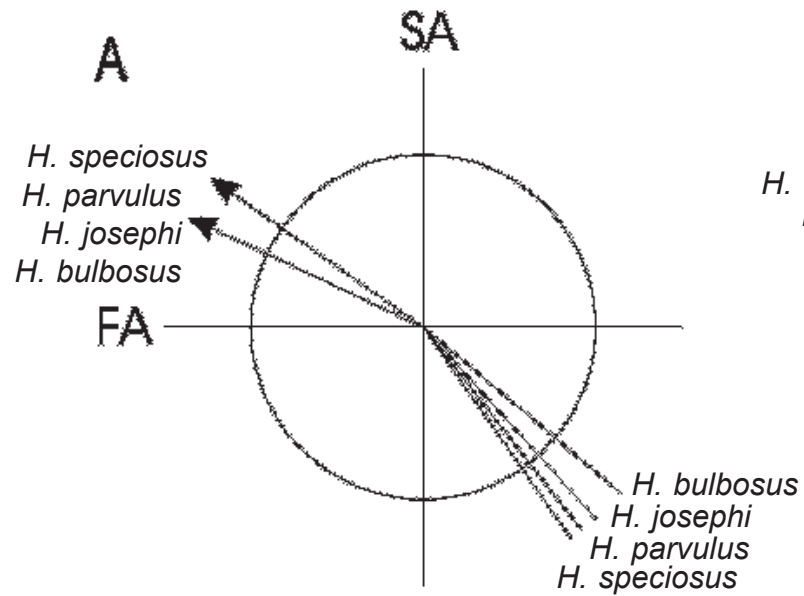

H. speciosus: $55^{\circ} 35^{\circ}$

H. parvulus: $65^{\circ} 38^{\circ}$

H. josephi: $\quad 65^{\circ} 42^{\circ}$

H. bulbosus: $65^{\circ} 50^{\circ}$

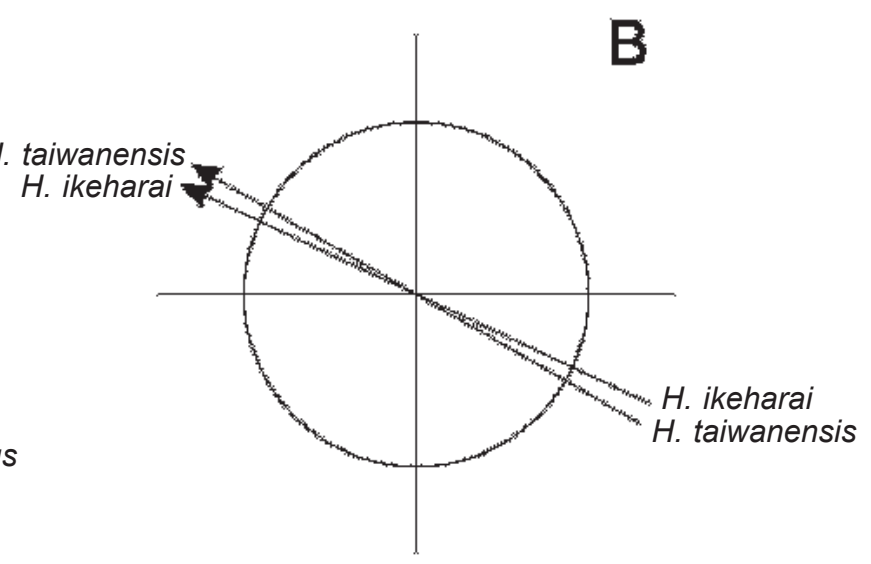

H. taiwanensis: $60^{\circ}$

H. ikeharai: $\quad 65^{\circ}$

\section{Females}

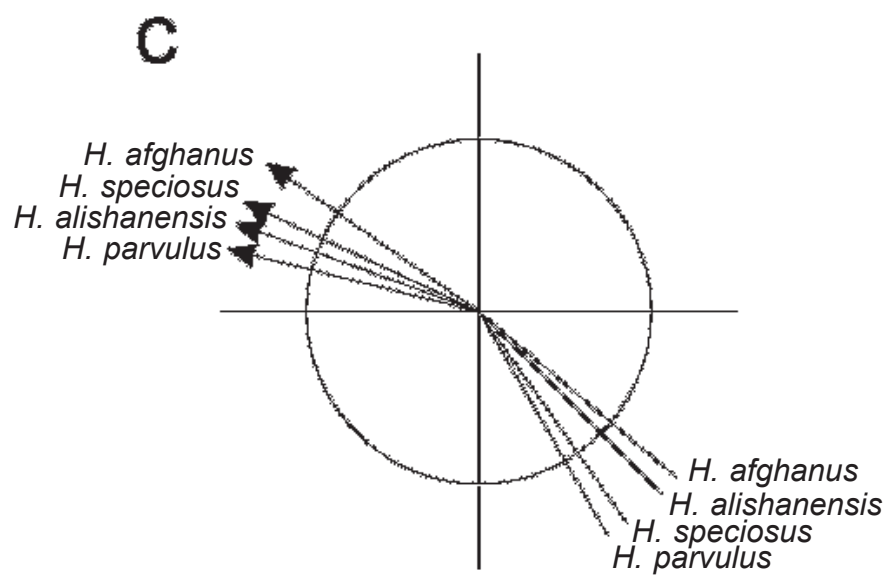

H. afghanus: $\quad 55^{\circ} 50^{\circ}$

H. alishanensis: $70^{\circ} \quad 45^{\circ}$

H. parvulus: $\quad 76^{\circ} 30^{\circ}$

H. speciosus: $65^{\circ} 35^{\circ}$

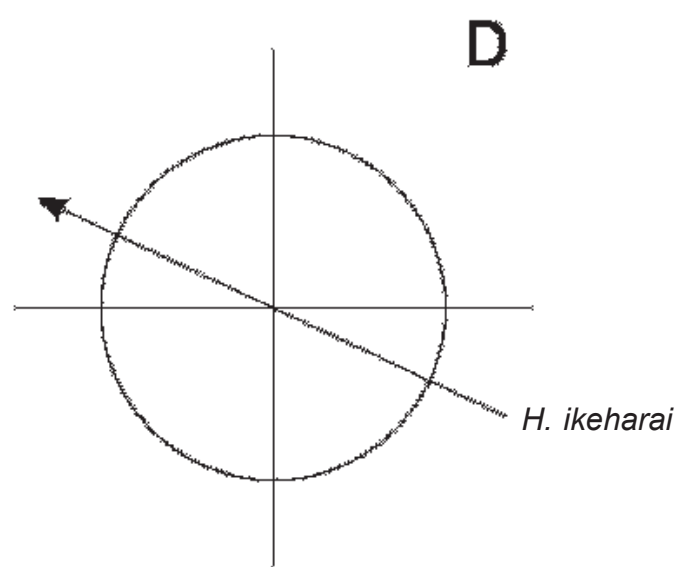

H. ikeharai: $65^{\circ}$

Fig. 4. - Diagrams of the various degrees of inclination of the axes of orientation to the sagittal axis in the species of the genus Heligmonoides Baylis, 1928 at mid-body. In the males, right axis inclined from $35^{\circ}$ to $65^{\circ}$ to the sagittal axis, left axis from $55^{\circ}$ to $65^{\circ}$ (A, B). In the females, right axis inclined from $30^{\circ}$ to $65^{\circ}$ to the sagittal axis, left axis from $55^{\circ}$ to $76^{\circ}$ (C, D).

All the diagrams are orientated as D. The degree of inclination of the species (single axis or left axis/right axis) is listed under each diagram. Abbreviations: FA: frontal axis; SA: sagittal axis; l: left side; v: ventral side. 
starting from a single oblique axis as the plesiomorphic state, this axis may undergo an independent rotation on the right and left sides, bringing about a doubleaxis state. In the most derived state when the rotation reaches $90^{\circ}$ for both sides the axis becomes simple once again and is superimposed to the frontal axis.

\section{ACKNOWLEDGEMENTS}

W e wish to thank Prof. A. Chabaud (Muséum national d'Histoire naturelle de Paris) and Dr. C. Vaucher (Muséum d'Histoire naturelle de Genève) for their valuable comments on the draft of the manuscript, Ms. Deborah Lynn Kay for reviewing the English, and Mr. Mohamed Tlemsani for comments concerning the geometrical aspects of the axis of orientation.

\section{REFERENCES}

BAYlIS H.A. On a collection of Nematodes from Nigerian mammals (chiefly rodents). Parasitology, 1928, 20, 280-304.

CABallero E. \& Cerecero C. Longistriata convoluta n. sp. (Nematoda: Trichostrongylidae) parásito del intestino de una tuza Cratogeomys merriami (Thomas). Anales del Instituto de Biología de México, 1943, 14, 201-205.

Denké M.A. Quatre nouveaux Nématodes Héligmosomes parasites de Rongeurs du Mexique. Bulletin du Muséum national d'Histoire naturelle, 1977, $3^{\text {ème }}$ série, $n^{\circ}$ 470, Zoologie, 327, 777-787.

Desset M.C. Le système d'arêtes cuticulaires chez les Nématodes Héligmosomes. II. Étude de cinq Longistriata parasites de Rongeurs africains. Cabiers de La Maboké, 1966, 4, 120-140.

Digiani M.C. \& Durette-Desset M.C. Two new species of Nippostrongylinae (Nematoda: Trichostrongylina: Heligmonellidae) from the grey leaf-eared mouse Graomys griseoflavus (Sigmodontinae) in Argentina. Parasite, 2003, 10, 21-29.

Dikmans G. New nematodes of the genus Longistriata in rodents. Journal of the Washington Academy of Sciences, 1935, 25, 7881.

Durette-Desset M.C. Étude du système des arêtes cuticulaires de trois Nématodes Héligmosomes: Longistriata kinsellai $\mathrm{n}$. sp., L. seurati Travassos et Darriba, 1929, L. hokkaidensis Chabaud, Rausch et Durette-Desset, 1963, parasites de Rongeurs. Annales de Parasitologie Humaine et Comparée, 1969, 44, 617624

Durette-Desset M.C. Description de Vexillata petteri n. sp., Nématode Héligmosome parasite d'un Rongeur néarctique. Annales de Parasitologie Humaine et Comparée, 1970a, 45, 289-293.

Durette-Desset M.C. Tenorastrongylus n. gen. (Nématode-Héligmosomatidé) parasite de Muridés. Annales de Parasitologie Humaine et Comparée, 1970b, 45, 823-828.

Durette-Desset M.C. Essai de classification des Nématodes Héligmosomes. Corrélation avec la paléobiogeographie des hôtes. Mémoires du Muséum national d'Histoire naturelle, 1971, nouvelle série, série A, Zoologie, 49, 1-126.

Durette-Desset M.C. Compléments morphologiques à l'étude de quelques Nématodes Héligmosomes, parasites de Rongeurs américains. Annales de Parasitologie humaine et comparée, 1972, 47, 243-249

Durette-Desset M.C. Nouvelles données morphologiques sur des Nématodes Trichostrongyloïdes des collections du Muséum national d'Histoire naturelle des États-Unis. Bulletin du Muséum national d'Histoire naturelle, 1978, $3^{\text {ème }}$ série, 513, Zoologie, 352, 135-147.

Durette-Desset M.C. Nouveaux Nématodes Trichostrongylö̈des parasites de Sauriens en Malaisie et à Bornéo. Bulletin du Muséum national d'Histoire naturelle, 1980, 4ème série, 2, section $\mathrm{A}, \mathrm{n}^{\circ}$ 3, 697-706.

Durette-Desset M.C. Trichostrongyloid nematodes and their Vertebrate hosts: reconstruction of the phylogeny of a parasitic group. Advances in Parasitology, 1985, 24, 239-306.

Durette-Desset M.C. \& Chabaud A.G. Note sur la nomenclature supra-familiale des Strongylida. Annales de Parasitologie Humaine et Comparée, 1993, 68, 111-112.

Durette-Desset M.C. \& Digiani M.C. Systematic position of some Nearctic Heligmosomoidea (Nematoda, Trichostrongylina) from the U.S. National Parasite Collection and their description. Journal of Parasitology, 2005.

Falcón-Ordaz J.S., Gardner S.L. \& Pérez-Ponce de León G. Vexillata liomyos n. sp. (Nemata: Ornithostrongylidae) from Liomys pictus (Rodentia: Heteromyidae) from Mexico, with comments on the synlophe of Vexillata armandae. Journal of Parasitology, 2001, 87, 656-659.

Gardner S.L., Fong E.V., Al Banna L. \& Raymond S.R. A new species of Vexillata (Nematoda: Ornithostrongylidae) from the coarse-haired pocket mouse (Chaetodipus hispidus) in New Mexico. Journal of Parasitology, 1994, 80, 591-594.

GuerRero R. Trichostrongyloidea parasites of Venezuelan wild mammals. III. The genus Vexillata (Travassos, 1937). Annales de Parasitologie Humaine et Comparée, 1984, 59, 253-261.

Hall M.C. Nematodes parasites of mammals of the orders Rodentia, Lagomorpha, and Hyracoidea. Proceedings of the United States National Museum, 1916, 50, 1-258.

Hasegawa H. Nematodes of the family Heligmonellidae (Trichostrongyloidea) collected from rodents of the Ryukyu Archipielago and Taiwan. Journal of Parasitology, 1990, 76, 470-480.

Hasegawa H. \& Otsuru M. Helminth fauna of the Ryukyu Archipielago, Japan. I. Tenorastrongylus ryukyensis n. sp. from Mus caroli in Okinawa Island (Nematoda: Heligmosomidae). Zoological Magazine, 1982, 91, 194-196.

Konno S. On Longistriata speciosa n. sp. from Apodemus speciosus. Medicine and Biology, 1958, 48, 56-58.

Ow Yang C.K., Durette-Desset M.C. \& Ohbayashi M. Sur les Nématodes parasites de Rongeurs de Malaisie. II. Les Trichostrongyloidea. Annales de Parasitologie humaine et comparée, 1983, 58, 467-492.

Tenora F. Parasitic nematodes of certain rodents from Afghanistan. Vestnic ceskoslovenska spolecnosti zoologické. Acta Societatis Zoologicae Bohemoslovacae, 1969, 33, 174-192.

Travassos L. Revisão da familia Trichostrongylidae Leiper, 1912. Monografias do Instituto Oswaldo Cruz, 1937, I, 1-512.

Wertheim G. \& Durette-Desset M.C. Helminthes de Mammifères et d'Oiseaux d'Israël. IV. La taxonomie et l'écologie des Nématodes Trichostrongylö̈des. Annales de Parasitologie humaine et comparée, 1975, 50, 735-762.

YoyotTE-VADO E. Étude de huit Nématodes parasites de Vertébrés du Vénézuela et de la Colombie. Bulletin du Muséum national d'Histoire naturelle, 1972, $3^{\text {ème }}$ série, 41, Zoologie, 35, 477-498.

Reçu le 17 février 2005

Accepté le 25 mars 2005 